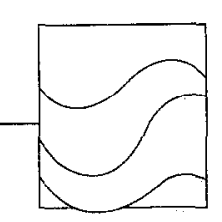

\title{
Long-term changes (1979-1994) in two coastal benthic communities (English Channel): analysis of structural developments
}

\author{
Dominique DAVOULT ${ }^{a}$, Jean-Marie DEWARUMEZ, Aline MIGNÉ ${ }^{b}$ \\ EP 1750 du CNRS, Université des sciences et technologies de Lille, Station marine, B.P. 80, 62930 Wimereux, France \\ ${ }^{a}$ E-mail: dom@loalit.univ-littoral.fr \\ ${ }^{\mathrm{b}}$ Present address: Laboratoire d'hydrobiologie, Université Pierre et Marie Curie, 12, rue Cuvier, 75005 Paris, France
}

(Received 14/03/96, revised 06/02/98, accepted 17/02/98)

\begin{abstract}
The long-term variations of two coastal benthic communities (Eastern English Channel, France) were studied between 1979 and 1994 by means of factor correspondence analysis (FCA), trophic structure and rank-frequency diagrams (RFD). FCA identified periods of relative homogeneity and periods of strong variation in the structure of the two communities. The first community, established on heterogeneous sand, showed a multi-annual cycle linked to grain-size variations in the sediment. As passive supplies of organic matter were not important and suspension feeders could hardly live in these conditions, the community remained poor and stable and was dominated by deposit-feeders and carnivores. The other one, a rich and diverse mussel (Mytilus edulis) bed, showed great variations in the abundance of the main species which generated the enrichment of the community by its suspension-feeding behaviour (biodeposition). Beyond these variations, the community remained stable until 1990 as no continuous trend or permanent change could be seen. Since 1990, no recruitment of $M$. edulis occurred and the relative dominance of suspension feeders, as well as the number of species, strongly decreased. During the following years, several species of tunicates (sessile suspension feeders with gregarious recruitment) recruited and partly took the ecological niche of $M$. edulis but they did not induce an increase of biodeposition and the previous richness was not restored. After a strong and rapid shift in the structure, a new equilibrium has been established within the community. (C) Elsevier, Paris
\end{abstract}

long-term series / benthos / factor analysis / rank-frequency diagrams / trophic structure

Résumé - Variations à long terme (1979-1994) de deux peuplements benthiques côtiers (Manche orientale, France) : analyse de l'évolution structurale. Les variations à long terme de deux peuplements benthiques côtiers ont été étudiées entre 1979 et 1994 au moyen d'analyses factorielles des correspondances (AFC), de l'étude de la structure trophique et des diagrammes rang-fréquence. Les AFC ont mis en évidence des périodes relativement homogènes et des périodes de variations importantes pour les deux peuplements. Le premier peuplement, établi sur des sables hétérogènes, montre une variation pluri-annuelle de sa structure fortement liée à celle de la granulométrie du sédiment. Les apports de matière organique étant assez faibles et les suspensivores étant peu abondants dans ce type de peuplement, celui-ci reste pauvre, relativement stable et dominé par les déposivores et les carnivores. Le deuxième peuplement, une moulière à $M y t i-$ lus edulis, présente de grandes variations de l'abondance relative de l'espèce principale M. edulis, à l'origine de l'enrichissement du peuplement et de la modification du sédiment par biodéposition. Au-delà de ces variations, la structure globale du peuplement paraissait stable jusqu'en 1990, quand aucun recrutement de M. edulis n'a été constaté. Après cette année-là, il semble qu'il n'y ait plus de recrutement de moules, ce qui s'est d'abord traduit par une baisse sensible du nombre d'espèces et de la dominance relative des suspensivores. Depuis, plusieurs espèces de Tuniciers (espèces sessiles suspensivores à recrutement grégaire) occupent la niche de M. edulis, mais leur activité suspensivore n'induit pas de bio- 
déposition susceptible d'enrichir le peuplement ou de modifier le sédiment et la richesse spécifique n'a pas été entièrement restaurée. Le peuplement a ainsi brusquement changé de structure pour constituer un nouvel équilibre stable à l'échelle de quelques années. (C) Elsevier, Paris

série à long terme / benthos / analyse factorielle / diagrammes rang-fréquence / structure trophique

\section{INTRODUCTION}

For some years, the study of long-term changes has been a continuing theme in marine biology. It reveals changes in the structure or the function of ecosystems at a scale higher than seasonal variations or climatic accidents. This leads to an understanding of how ecosystems may integrate these variations during subsequent years $[9$, $10]$, or react over a very long period to the small but continuous influence of variations such as climatic global change.

Data series, mainly planktonic, have existed for several decades, but few long-term studies have been carried out on benthic communities, with a few notable exceptions $[3,5,15,19]$. Recently, both international (e.g. the COST 647 project for E.U.) and national (e.g. PNOC "Séries à long terme" in France) programmes have initiated the development of time series in coastal benthic communi- ties $[2,16]$. However, most studies are concerned with the dynamics of a single or a few dominant species.

In this paper, an attempt is made to analyse the general structural devclopment of two coastal benthic communities in the Eastern English Channel (figure 1), a heterogeneous sand community and a mussel (Mytilus edulis) bed, between 1979 and 1994. A previous study [12] covering the period 1979-1990 showed both periods of relative homogeneity and periods of strong variations in the structure of these communities. These variations appeared to be due to a single factor in both cases: grain-size variations in the heterogeneous sand community and recruitment variability of Mytilus edulis, the main species in the mussel bed, which changed the intensity of biodeposition favourable to the increase of the number of species.

Whereas multivariate analyses were commonly used for spatial studies of benthic communities, time series were usually described with rough data (species richness, den-

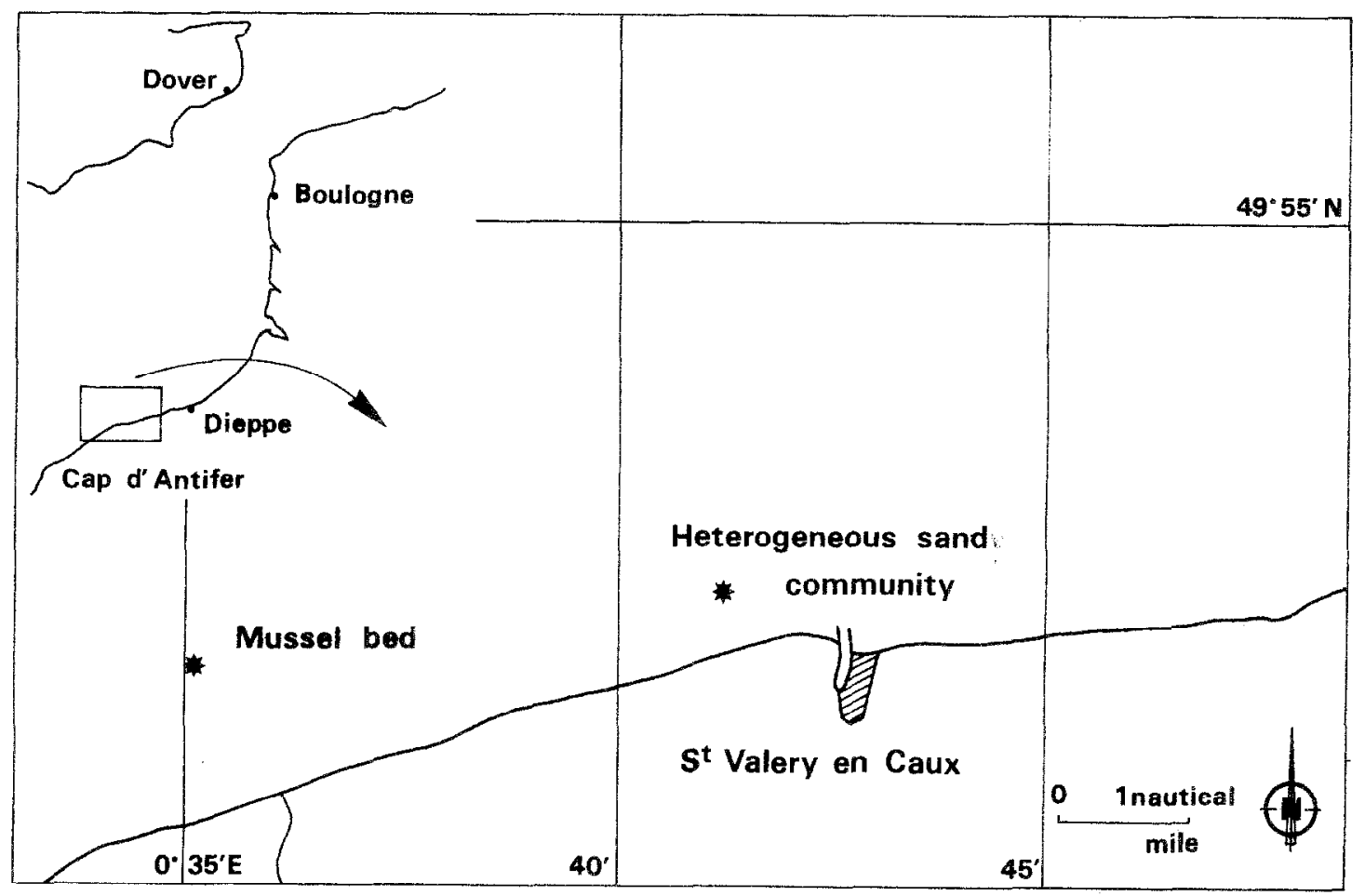

Figure 1. Location of the two benthic communities. 
sity or biomass) or synthetic indices (e.g. the Shannon index) and the interpretation was based on main species $[18,20]$. In this paper, factor correspondence analysis (FCA) was used to define the different sequences of the multi-annual development of the two communities objectively. The interpretation of the segmentation of time series due to the FCA is discussed and supported by results obtained using rank-frequency diagrams (RFD) and the trophic structure of the two communities. Grainsize variations of the sediment were also taken into account. This paper aims to examine the following:

- in the heterogeneous sand community, to observe whether the shift in the structure of the community following grain-size variations, from fine sands to gravels (due to winter storms?) with a progressive return to the original structure, led to further variations within the same multi-annual cycle or to other kinds of variations of the community structure,
- in the mussel bed, to establish whether the complete disappcarance of the main species, Mytilus edulis, due to the lack of recruitment, which induced a deep change in the structure of the community and the appearance (and persistence ?) of a species with similar characteristics as $M$. edulis, led to a resilient community structure and a recovery of the previous diversity.

\section{MATERIAL AND METHODS}

Two neighbouring macrobenthic communities, a heterogeneous sand community ( $8 \mathrm{~m}$ depth) and a coastal mussel (Mytilus edulis) bed (10 $\mathrm{m}$ depth), were studied. The main characteristics and spatial distribution of benthic communities in the Eastern English Channel have been previously described $[7,8]$. The area is characterized by tidal currents $>2.8$ knots during spring tide [1]. Benthic

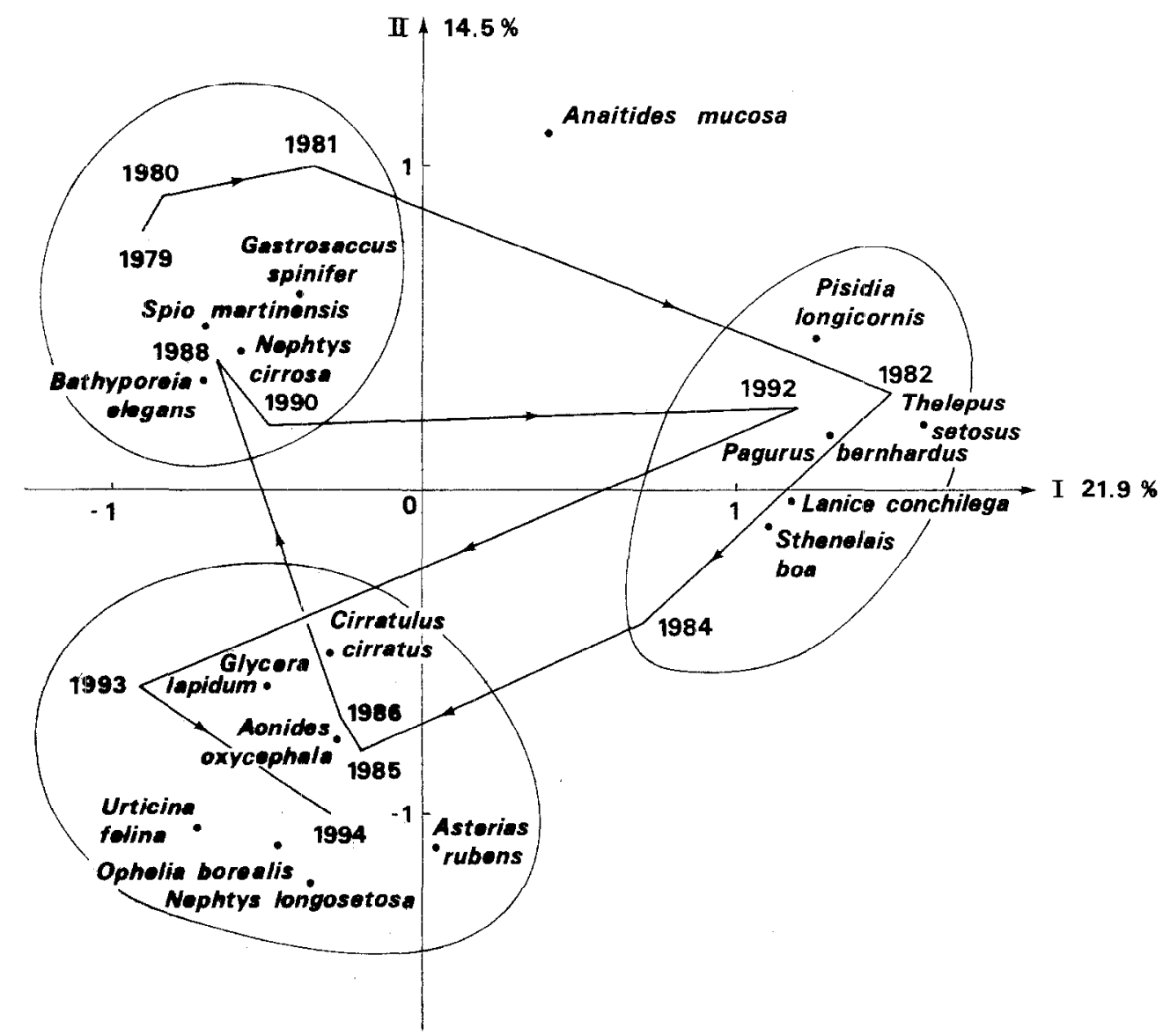

Figure 2. FCA of the heterogeneous sand community (1979-1994). Projection of years and structuring species in the plane of the factorial axes I and II. 
samples were taken in spring, every year from 1979 to 1986, in 1988, 1990 and from 1992 to 1994, with a Rallier du Baty dredge (one sample of $30 \mathrm{~L}$ of sediment). This volume is considered in the English Channel as sufficient to collect the main species [6] and to assess their relative dominance [11]; moreover, some replicates were carried out previously in these communities (three dredgings per station) which confirmed the representativeness of a single $30 \mathrm{~L}$ sample. Samples were sieved on a $1 \mathrm{~mm}$ mesh to collect only macrofauna. Although the two communities were sampled several times at several stations during all these years, in this study we only present data recorded every year in May or early June.

Factor correspondence analysis (FCA) [4] was performed for each community after elimination of rare species (one individual of the species sampled only once). Species used for the interpretation and represented in the figures had a relative contribution (CTR) greater than the hypothesis of an equal contribution of each species in the analysis, i.e. $1 / \mathrm{n}$ for a FCA performed on a matrix of $\mathrm{n}$ species. Square cosine $\left(\operatorname{COS}^{2}\right)>0.5$, that measure the quality of the representation of variables and objects on the plane of the projection, were also taken into account. Results were then compared with the temporal evolution of rank-frequency diagrams (RFD) [14] and of the trophic structurc (based on abundance data), taking into account only three trophic groups as previously defined $[11,12]$.

\section{RESULTS}

\subsection{The heterogeneous sand community}

This community was poor in species $(11 \pm 6$ species per sample). The FCA was performed on a 33 species $x$ 12 year matrix (the elimination of rare species led to the removal of the year 1983). 17 species had a CTR $>3 \%$ $(\approx 1 / 33)$ on one of the two main axes. The three main axes only described $48.7 \%$ of the total inertia. Temporal variations of the global structure were interpreted on axes I and II of the HCA (figure 2). 'These two axes clearly separated three groups:

- the first one (1979 to 1981,1988 and $1990 ; \Sigma C T R=$ $22.1 \%$ on axis I) was dominated by typical sand species (Spio martinensis, Nephtys cirrosa, Gastrosaccus spinifer and Bathyporeia elegans);

- the second one $(1982,1984$ and $1992 ; \Sigma C T R=70.4 \%$ on axis I) was dominated by an epifauna characteristic of coarser sediments (Sthenelais boa, Thelepus setosus, Pisidia longicornis and Pagurus bernhardus);
- the third one $(1985,1986,1993$ and $1994 ; \Sigma \mathrm{CTR}=$ $47.2 \%$ on axis II) was composed of both sand species (Ophelia borealis, Aanides oxycephala and Nephtys longosetosa) and species of gravels and pebbles (Urticina felina, Cirratulus cirratus and Asterias rubens).

Mean grain-size characteristics of the three groups of samples were calculated (table I): they showed a mean state in 1985, 1986, 1993 and 1994 with a sediment dominated by medium and coarse sands, then, on the one hand, a shift to a finer sediment from 1979 to 1981, in 1988 and in 1990, and, on the other hand, a shift to a coarser sediment in 1982, 1984 and 1992.

RFD did not vary a lot (figure 3) and kept a strongly convex shape, withstanding a faunal change and numerous permutations of ranks between species, except in 1985 (co-abundance of the nine dominant species: dominances between 5 and $15 \%$ ), in 1986 (Ophelia borealis represented $36 \%$ of individuals) and in 1992 (Thelepus setosus represented $28 \%$ of individuals).

The trophic structure (figure 4) showed the dominance of carnivores between 1979 and 1990 , the increase of suspension feeders in 1983 and 1984 and of deposit feeders

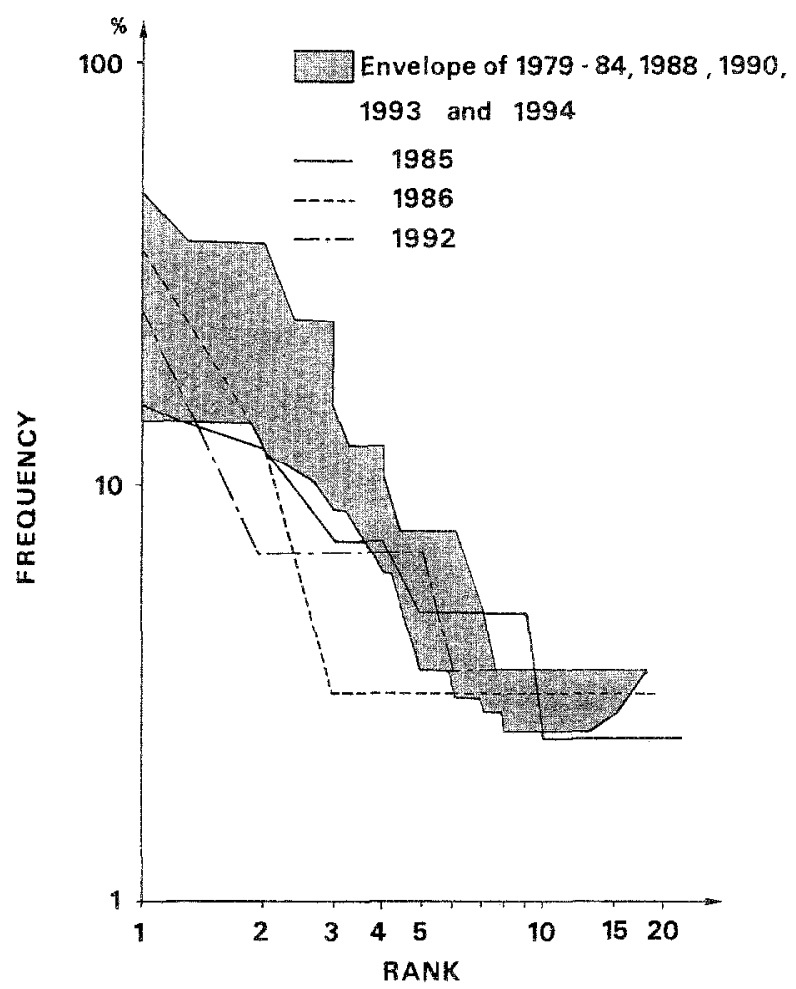

Figure 3. Temporal variation of RFD of the heterogeneous sand community. 
Table I. Heterogeneous sand community. Grain-size characteristics ( $\%$ of dry weight \pm standard deviation).

\begin{tabular}{lccc}
\hline Years & $\begin{array}{c}\text { 1985-1986-1993-1994 } \\
\text { (mean state) }\end{array}$ & $\begin{array}{c}\text { 1979-1980-1981-1988-1990 } \\
\text { (medium sands) }\end{array}$ & $\begin{array}{c}\text { 1982-1984-1992 } \\
\text { (coarse sediment) }\end{array}$ \\
\hline Pebbles $(>20 \mathrm{~mm})$ & $1.7 \pm 3.4$ & $1.4 \pm 1.4$ & $13.1 \pm 10.3$ \\
Coarse gravels $(5-20 \mathrm{~mm})$ & $6.1 \pm 7.2$ & $2.6 \pm 4.8$ & $16.3 \pm 11.1$ \\
Fine gravels $(2-5 \mathrm{~mm})$ & $4.6 \pm 6.0$ & $4.4 \pm 6.8$ & $6.9 \pm 1.5$ \\
Coarse sands $(0.5-2 \mathrm{~mm})$ & $19.4 \pm 19.2$ & $13.9 \pm 16.5$ & $25.4 \pm 21.1$ \\
Medium sands $(0.2-0.5 \mathrm{~mm})$ & $60.8 \pm 30.6$ & $64.7 \pm 24.1$ & $34.6 \pm 14.0$ \\
Fine sands $(0.05-0.2 \mathrm{~mm})$ & $6.6 \pm 6.5$ & $12.0 \pm 9.4$ & $3.5 \pm 3.3$ \\
Silts $(<0.05 \mathrm{~mm})$ & $0.9 \pm 1.6$ & $1.1 \pm 1.2$ & $<0.1$ \\
\hline
\end{tabular}

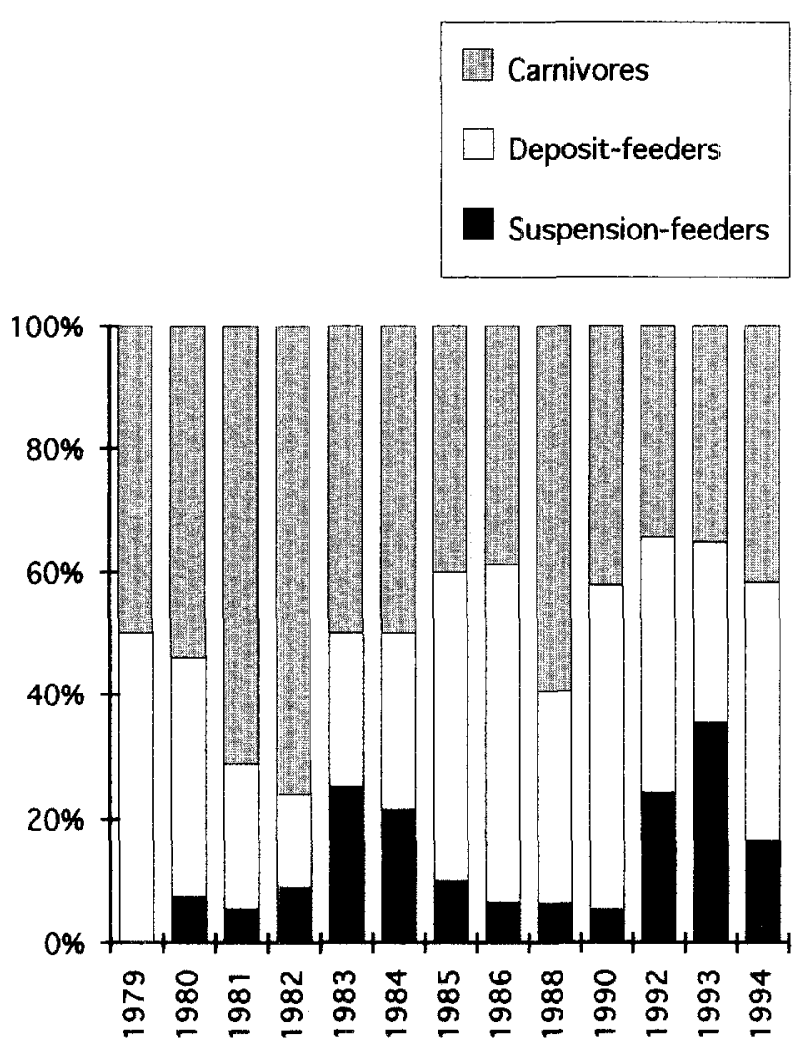

Figure 4. Temporal variation of the trophic structure (relative abundance) of the heterogeneous sand community.

in 1985, 1986 and 1990. During 1992-1994, the proportion of suspension feeders increased whereas that of carnivores decreased.

\subsection{The mussel bed}

The number of species was higher in this community ( $34 \pm 16$ species per sample). The FCA was performed on a 87 species $\times 13$ year matrix (1979-1994) (figure 5).
16 species had a CTR $>1.15 \%(\approx 1 / 87)$ on one of the two main axes. These two axes described $59.1 \%$ of the total inertia.

On axis I, the group of objects 1992, 1993 and 1994 ( $\Sigma \mathrm{CTR}=96.8 \%)$ was characterized by the dominance of five species of tunicates: Ascidia conchilega, Dendrodoa grossularia, Molgula manhattensis, Styela coriacea and Styela clava $\left(\sum \mathrm{CIT}=55.4 \%\right)$. The latter was a new species for the area [13] but the other ones were present in low abundance on pebbles in the area. Other characteristic species (Polynoe scolopendrina, Sabellaria spinulosa, Thelepus setosus and Crepidula fornicata, $\Sigma$ CTR = $38.8 \%$ ), are common species of pebbles communities of the Eastern English Channel [11], but were rare or absent in the mussel bed between 1979 and 1990. This group was opposed to a group of five years (1980 to 1982, 1985 and 1986) characterized by a high abundance of Mytilus edulis ( $>1000$ individuals per sample, i.e. $>80 \%$ of the individuals; $\Sigma$ CTR $=9.8 \% ; \operatorname{COS}^{2}=0.63$ ). Samples of 1979 and 1990 were projected between these two groups of years because they were characterized by the absence of $M$. edulis, but not by the relative abundance of new species such as tunicates.

Axis II was characterized by the year 1983 (CTR = $71.7 \% ; \operatorname{COS}^{2}=0.91$ ), where main species were Cirratulus cirratus, Caulleriella alata, Anaitides mucosa, Pisidia longicornis and Pilumnus hirtellus ( $\mathrm{CTR}=$ $77.8 \%$ ), all being common species in the community. $M$. edulis remained abundant (904 sampled individuals) but its relative dominance decreased ( $42 \%$ of sampled individuals).

Mean grain-size characteristics were calculated (table II) for three groups of years defined by the relative abundance of M. edulis and tunicates: two groups clearly isolated by the FCA and a third one constituted with the other years (1979, 1983, 1984, 1988 and 1990). When 


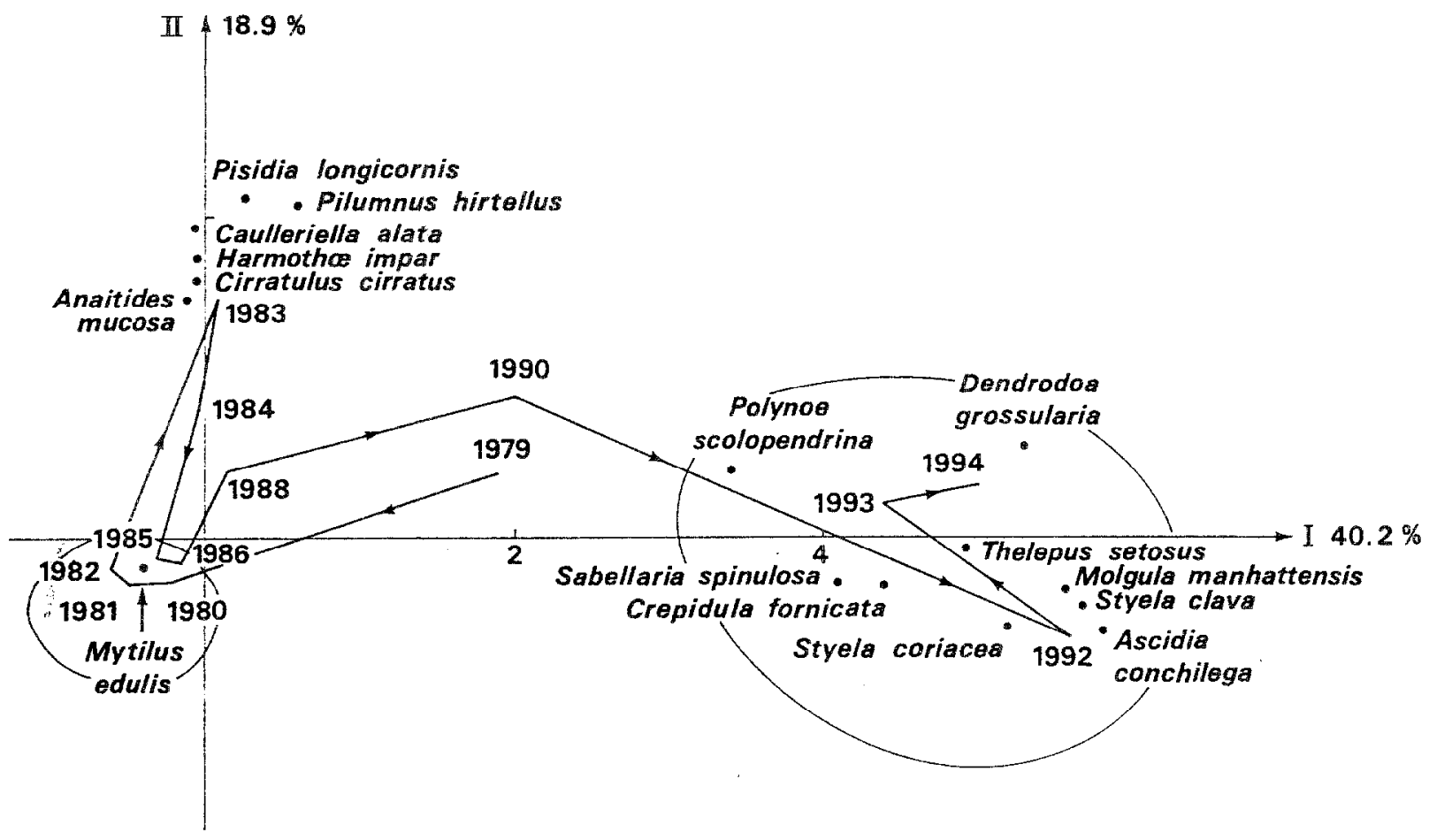

Kigure 5. FCA of the mussel bed community (1979-1994). Projection of years and structuring species in the plane of the factorial axes I and II.

M. edulis was very abundant, medium sands were dominant. This could be the result of the biodeposition due to the suspension-fecding activity of the species. When M. edulis was less abundant (1983, 1984 and 1988) or absent for a short period (1990, maybe 1979), the sediment was more heterogeneous and mainly composed of coarse sands and pebbles. On the contrary, when no recruitment of $M$. edulis occurred for several years and the ascidians became dominant (1992, 1993 and 1994), the sediment was mainly dominated by pebbles and coarse gravels, i.e. the sediment found offshore [12].

Two characteristic shapes of RFD could be defined, with some intermediate stages (figure 6): a sigmoid shape (and a greater number of species) when $M$. edulis was strongly dominant and a convex shape (and a lower number of species) when several species of ascidians replaced M. edulis in the community. Intermediate stages corresponded to periods of lower dominance of $M$. edulis (1983, 1984 and 1988) and periods without recruitment of M. edulis (1979 and 1990) but without a great change in the specific composition.

During the first period of study, the trophic structure (figure 7) varied strongly with dominance of a single species, $M$. edulis, and opposed the same groups of years as shown by the FCA. In 1990, the proportion of suspension feeders was very low, but it increased during the follow-

Tahle II. Mussel hed. Grain-size characteristics (\% of dry weight \pm standard deviation).

\begin{tabular}{lccc}
\hline Years & $\begin{array}{c}\text { 1980-1981-1982-1985-1986 } \\
\text { (mussel bed) }\end{array}$ & $\begin{array}{c}\text { 1979-1983-1984-1988-1990 } \\
\text { (mussels rare or absent) }\end{array}$ & $\begin{array}{c}\text { 1992-1993-1994 } \\
\text { (no mussel but ascidians } \\
\text { common) }\end{array}$ \\
\hline Pebbles $(>20 \mathrm{~mm})$ & $15.7 \pm 10.8$ & $26.1 \pm 25.7$ & $63.6 \pm 53.6$ \\
Coarse gravels $(5-20 \mathrm{~mm})$ & $10.8 \pm 3.8$ & $5.8 \pm 4.5$ & $34.8 \pm 54.6$ \\
Fine gravels $(2-5 \mathrm{~mm})$ & $8.2 \pm 3.9$ & $7.9 \pm 4.9$ & $0.6 \pm 0.9$ \\
Coarse sands $(0.5-2 \mathrm{~mm})$ & $15.8 \pm 8.2$ & $25.5 \pm 8.0$ & $0.9 \pm 1.2$ \\
Medium sands $(0.2-0.5 \mathrm{~mm})$ & $41.3 \pm 20.2$ & $29.0 \pm 11.6$ & $0.1 \pm 0.1$ \\
Fine sands $(0.05-0.2 \mathrm{~mm})$ & $5.1 \pm 1.8$ & $3.6 \pm 1.5$ & $<0.1$ \\
Silts $(<0.05 \mathrm{~mm})$ & $0.6 \pm 0.7$ & $2.0 \pm 3.8$ & $<0.1$ \\
\hline
\end{tabular}




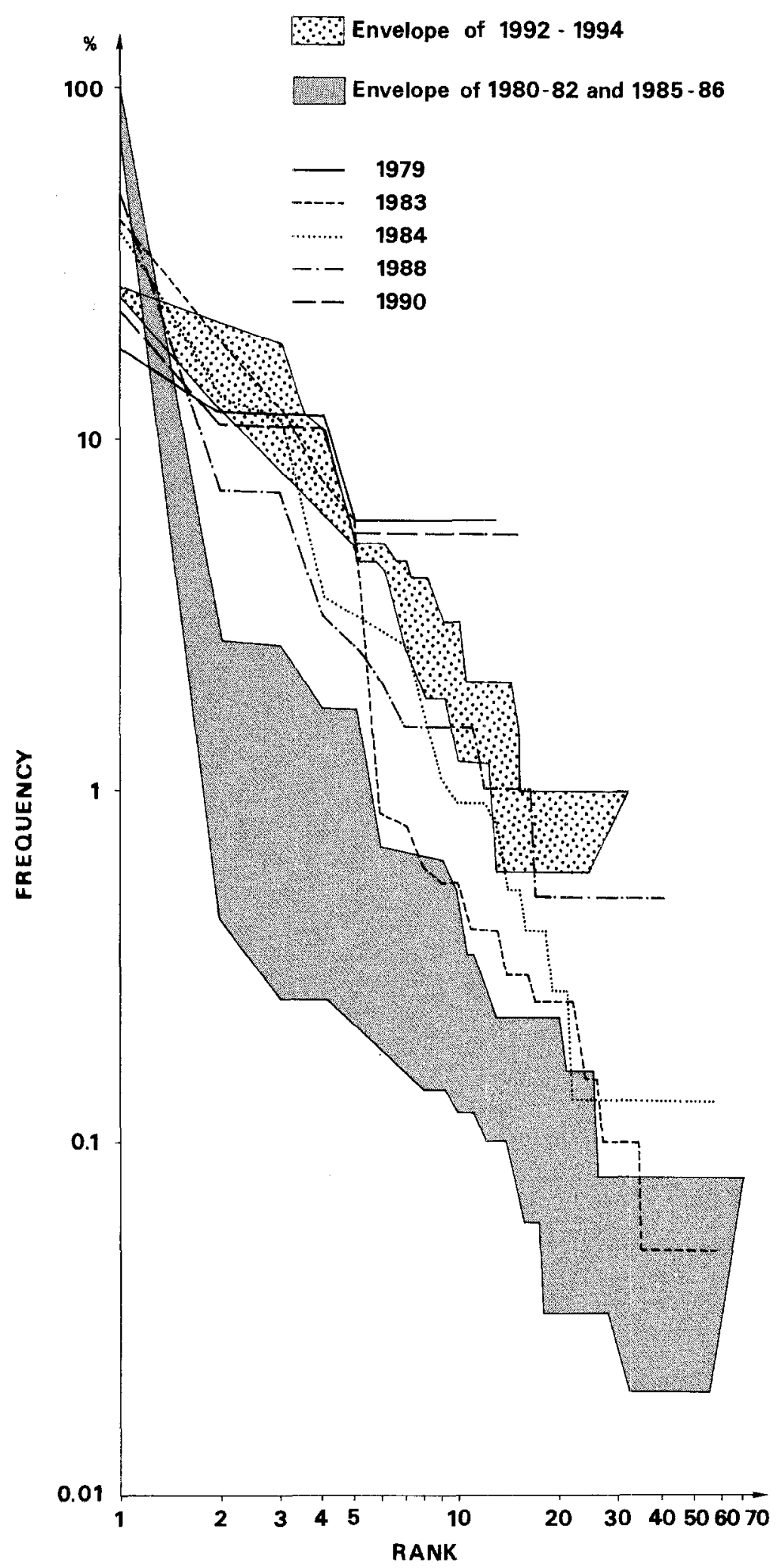

Figure 6. Temporal variation of RFD of the mussel bed community. 
ing years because of the recruitment of ascidians. The trophic structure, although varying within years, remained quite different from the previous stage.

\section{DISCIUSSION}

As was shown in a previous study [12], FCA performed on the two benthic communities clearly showed cyclic variations in structure. Time series showed both homogeneous periods (groups of years) and greater or lesser variations. So, FCA can highlight clustering [17] and more or less continuous trends or gradients equally well [11]. However, variations in structure shown by FCA could be due to variations in relative abundance of a few or more species. Thus, in order to get a real ecological interpretation, the strength of results was evaluated using other criteria such as RFD or trophic structure which confirmed the interpretation made with FCA in this study.

FCA performed on samples of the heterogeneous sand community showed great variations in species composition (figure 2). The development appeared to be linked to grain-size variations of the sediment (table l). Granulometry of the sediment sampled in autumn (unpublished data) confirmed the spring results. So it was assumed that in some years, very strong winter storms could remove sand in this shallow coastal area and change characteristics of the sediment before spring (e.g. between 1981 and 1982, figure 2). Then, the sand content slowly increased during subsequent years and the species composition of the community followed this development. The trophic structure (figure 4) also changed quickly and suspension-feeders, generally very rare, became more abundant when sediment grain-size increased. This assumption was consistent with the fact that the temporal development was structured in a single way cycle (figure 2): the community structure always evolved directly from a sandy stage to a pebbly stage, then to an intermediate stage before recovering the initial sandy stage. RFD showed that, despite great variations in species composition, the global structure of the community stayed quite stable (figure 3), which suggested that the functioning of the community did not change drastically because food supplies were not modified within years.

The coastal mussel bed showed great variations between 1979 and 1990 (figure 6) linked to the great variations in abundance of the main species, $M$. edulis. These variations depended both on the decrease in the relative abun-

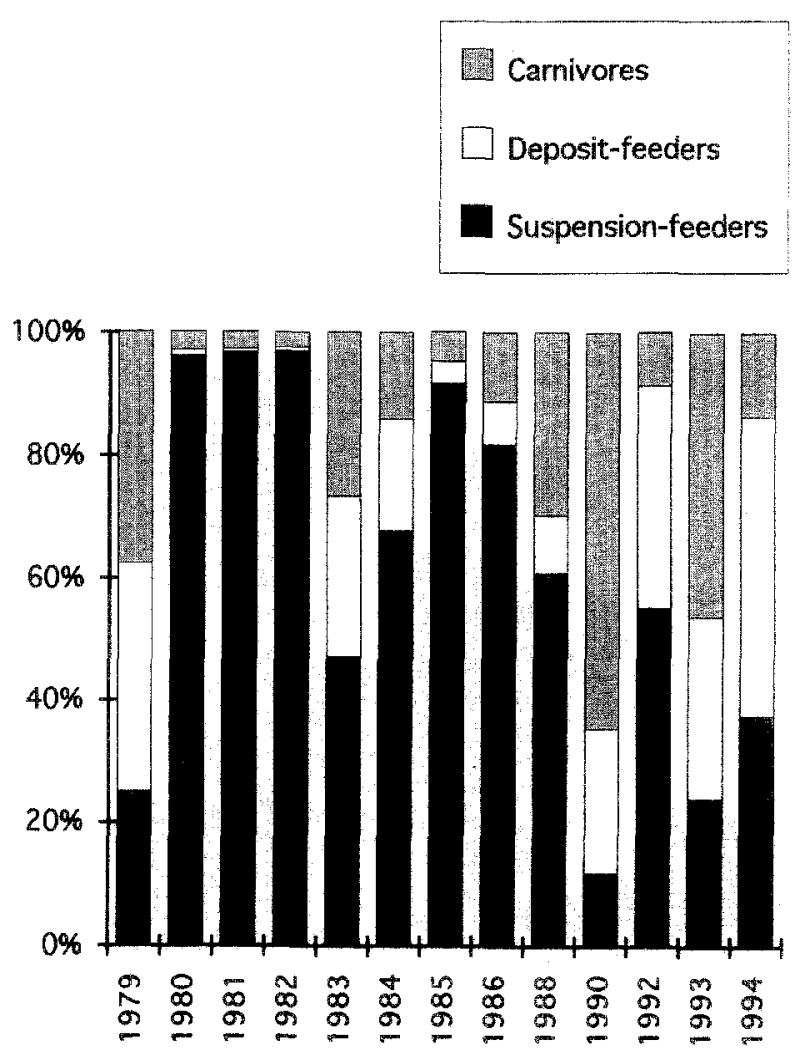

Figure 7. Temporal variation of the trophic structure (relative abundance) of the mussel bed community.

dance of this species (40 to $50 \%$ in 1983,1984 and 1988, no individual in 1979 and 1990) and on the increase of relative abundance of species that were usually rare in the community. On the one hand, there is no trawling in the area or exploitation of this mussel bed and, on the other hand, size distributions of M. edulis before 1990 (not presented) indicated the occurrence of annual recruitments. The critical phase of larval transport could be responsible for the great variations in the dominance of the main species. During this period, the granulometry of the sediment remained stable [12], and RFD followed the same development. In autumn 1990, when M. edulis was not present, a species with some similar characteristics (a suspension feeder with gregarious recruitment), the ascidian Molgula manhattensis, became dominant (87.7\% of relative abundance, [12]). This event was not coincidental as, during the following period (19921994), no recruitment of $M$. edulis occurred, but other ascidians became dominant and the community structure shifted to a new stage which remained stable for three years (figure 5); thus, a new benthic community now 
occurs in the same area. RFD clearly showed this change (figure 6); the number of species decreased when no M. edulis occurred in 1979 and 1990. It has remained lower since 1990 than between 1980 and 1988, surely because the suspension-feeding activity of ascidians did not induce the same biodeposition as the one induced by $M$. edulis and so did not change the sediment (table II) enough to diversify the biotope to shelter both epifauna and infauna.

In this study FCA appeared to be a good and reliable method for studying temporal variations of benthic communities. It allowed several levels of heterogeneity to be detected objectively. Complementary methods such as RFD and the study of the trophic structure allowed an evaluation of the strength and the significance of struc- tures identified by FCA. Time series of approximately ten years appeared to be too short to include even large variations due to localised events. In this study, the heterogeneity shown in the sand community between 1979 and 1990 allowed variations which occurred until 1994 to be explained. On the contrary, it was impossible to predict the shift that appeared in the mussel bed.

\section{Acknowledgements}

The authors are grateful to D. Menu who drew some figures, to I. and A. Richard who carried out some samplings. Data were obtained through Ifremer/EDF contracts.

\section{REFERENCES}

[1] Anonymous, Abords de St Valéry-en-Caux, des Grandes Dalles à la pointe d'Ailly, Service Hydrographique et Océanographique de la Marine, France, carte 6794 D (1979).

[2] Bachelet G., Castel J., (eds) Long-term changes in marine ecosystems, Oceanol. Acta, 20, 1 (1997) 1-331.

[3] Barnett P.R.O. Watson J., Long-term changes in some benthic species in the Firth of Clyde, with particular reference to Tellina tenuis, Proc. R. Soc. Edinburg, Sect. B, 90 (1986) $287-$ 302.

[4] Benzecri J.P., L'analyse des données. II: l'analyse des correspondances, Dunod, 4e éd., Paris, 1982, 632 pp.

[5] Buchanan J.B. Moore J.J., A broad review of variability and persistence in the Nothumberland benthic fauna (1971-1985), J. mar. biol. Ass. U.K., 66 (1986) 641--657.

[6] Cabioch L., Contribution à la connaissance des peuplements benthiques de la Manche occidentale, Cah. Biol. Mar., IX, 5 (suppl.) (1968) 493-720.

[7] Cabioch L., Glaçon R., Distribution des peuplements benthiques en Manche orientale, de la baie de Somme au Pas de Calais, C.R. Acad. Sci. Paris, sér. D, 280 (1975) 491-494.

[8] Cabioch L., Glaçon R., Distribution des peuplements benthiques en Manche orientale, du cap d'Antifer à la baie de Somme, C.R. Acad. Sci. Paris, sér. D, 285 (1977) 209-212.

[9] Dauvin J.C., Évolution à long terme (1978-1986) des populalions d'Amphipodles des sables fins de la Pierre Noire (Baie de Morlaix, Manche Occidentale) après la catastrophe de l'Amoco Cadiz, Mar. Envir. Res., 21, (1987) 247-273.

[10] Dauvin J.C., Effets à long terme de la pollution de l'Amoco Cadiz sur la production de deux peuplements subtidaux de sédiments fins de la Baie de Morlaix (Manche Occidentale), in: Estuaries ans coasts: spatial and temporal intercomparisons, Proceedings of the ECSA 19 Symposium (Elliot M., Ducrotoy J.P., edls), Olsen \& Olsen, Fredensborg, Denmark (1991) 349-358.
[11] Davoult D., Biofaciès et structure trophique du peuplement des cailloutis du Pas de Calais (France), Oceanol. Acta 13 (1990) $335-348$.

[12] Davoult D., Dewarumez J.M., Frontier S., Long-term changes (1979-1990) in three benthic communities (Eastern English Channel): use of factor analysis and rank-frequency diagrams for studying structural developments, Neth. J. Aquat. Ecol. 27 (1993) 415-426

[13] Davoult D., Dewarumez J.M., Glaçon R., Nouvelles signalisations d'espèces macrobenthiques sur les côtes françaises de la Manche orientale et de la Mer du Nord. IV, Groupes divers, Cah. Biol. Mar. 34 (1993) 55-64.

[14] Frontier S., Diversity and the structure in aquatic ecosystems, Oceanogr. Mar. Biol. Ann. Rev. 23 (1985) 253-312.

[15] Glémarec M., Les fluctuations temporelles des peuplements benthiques liées aux fluctuations climatiques, Oceanol. Acta 2 (1979) 365-371.

[16] Heip C., Keegan B.F., Lewis J.R., eds Long-term changes in coastal benthic communities. Proc. Symposium, Brussels, Belgium, December 9-12, 1985, Developments in Hydrobiology, Dr W. Junk publ., Dordrecht, The Netherlands (1986).

[17] Legendre L., Legendre P., Ecologie numérique. 2. La structure des données écologiques, Masson, Paris, Collection Ecologie (1984).

[18] Pearson T.H., The Loch Eil project: population fluctuations in the macrobenthos, J. Exp. Mar. Biol. Ecol. 56 (1982) 305-321.

[19] Pearson T.H., Duncan G., Nuttall J., Long-term changes in the benthic communities of Loch Linnhe and Loch Eil (Scotland), Hydrobiologia 142 (1986) 113-119.

[20] Rees E.I.S., Walker J.M., Annual and spatial variation in the Abra community in Liverpool Bay, Oceanol. Acta 6 (1983) $165-169$. 